\title{
Phytoplankton community and their impact on water quality: An analysis of Hollingsworth Lake, UK
}

\section{CECILIA MEDUPIN}

\author{
National open university of Nigeria, 14/16 Ahmadu Bello Way, Victoria Island, Lagos Nigeria
}

\begin{abstract}
Algal bloom had been a problem on the Hollingworth Lake in years' past to the locales and the lake's biodiversity. In order to assess the status of the lake, the lake's phytoplankton and water quality were examined during the study period of June to August 2004) at three lake depths. 49 species belonging to 7 different classes were identified including Dinophytes, Cyanophytes, Baccilariophytes, Chlorophytes, Cryptophytes, Euglenophytes and Crysophytes. The most representative class in terms of species richness was Dinophyceae (2species) and dominated by Ceratium hirudinella. Cyanobacteria had 13 species and was dominated by Microcytis flos aquae, Baccilariophytes had 10 species, Chlorophytes had 15 species, Cryptophytes (4 species), Chrysophytes ( 2 species) and the least of the species was Euglenophyte as it contributed with lower biovolume values. The total biovolumes of the phytoplankton species including Microcystis Flos aquae and Oscillatoria aghardii increased progressively following the increase in temperature over the summer months with a mean level of temperature was $17^{\circ} \mathrm{C}$, pH-7.72; conductivity of $0.199 \mathrm{~ms} / \mathrm{cm}$ and Dissolved Oxygen, $87 \%$. When the lake's chemical components, phytoplankton composition and phytoplankton biomass were compared with international technical standards for measurement, including the World Health Organisations' standard for water quality and the EC Directive for good quality water, the results indicated the lake to fall within the mesotrophic-eutrophic status. At the time of this study, the lake was not susceptible to generating algal blooms. @JASEM
\end{abstract}

\section{Keywords: phytoplankton, water quality, biomass}

Phytoplankton communities are sensitive to changes in their environment and therefore phytoplankton total biomass and many phytoplankton species are used as indicators of water quality (Reynolds 1997, Reynolds et al. 2002, Brettum and Andersen 2005). Phytoplankton communities give more information on changes in water quality than mere nutrient concentrations or chlorophyll-a concentration. Water quality is an ensemble of physical, chemical and biological characteristics of the given water (Straskraba and Tundisi 1999) Following this knowledge, eutrophication of freshwater is regarded as a water quality issue which results in the deterioration of the aquatic environment and impacts on water usage. Cyanobacteria have been recognised as a major symptom of eutrophication in fresh water as their blooms are prevalent in waters affected by cultural nutrient enrichment (Reynolds 1984a, Moss 1998). This paper analysis phytoplankton abundance, physical and chemical parameters to measure water quality.

\section{MATERIALS AND METHODS}

Samples were collected from three sites along the Hollingsworth Lake, United Kingdom on a biweekly sampling routine.

Phytoplankton: A net of small mesh size of $53 \mu \mathrm{m}$, used to trawl samples horizontally on the lake. The net was lowered gently and trawled at a distance of $2 \mathrm{~m}$ for 3 minutes at constant speed. The horizontal trawl net sample was used to identify large phytoplankton $(>50 \mu \mathrm{m})$ and the sample was fixed with 4\% Lugol's solution to preserve the phytoplankton collected. Taxa are identified according to identification keys of Cander-Lund and

*E-mail: cmedupin@yahoo.com
Lund 1995. An inverted microscope procedure of Utermohl as described by Lund et al. (1958) was used to identify and to count phytoplankton taxa. For enumeration of rare, large taxa, the entire chamber is subsequently scanned and counted at low magnification. Results are expressed as cells $/ \mathrm{ml}$ (Downing and Rigler 1984) for all algal taxa.

Chlorophyll-a was analysed using the CECIL CE 20011 spectrophotometer at wavelengths of $665 \mathrm{~nm}$ and $750 \mathrm{~nm}$, to correct for turbidity, while depth samples were taken using standard sampling techniques for standing waters. Also readings were taken from an integrated water sample for Temperature, Dissolved Oxygen, pH, and Conductivity using a previously standardised YSi (Yellow Springs Instrument Company) multi-meter probe and the results recorded. Analysis of nutrients was carried out using the analyser by Skalar Sans Plus System auto analyser. (Skalar,1993) Nutrients analysed included Nitrogen, Phosphorus and Silicates and the transparency of the water column was determined using a Secchi disc on the three sample sites and using standard measurements.

\section{RESULTS AND DISCUSSION}

Phytoplankton: The species are listed according to their abundance in the lake as follows: Dinophytes, Cyanophytes, Baccilariophytes, Chlorophytes, Cryptophytes, Euglenophytes and Crysophytes. Hollingworth Lake is diverse as it had 49 taxa with more diverse population in August. The lowest diversity was recorded in June.

The most abundant taxon was Ceratium hirudinella spp. which accounted for an average of $93 \%$ of the total phytoplankton sampled at the end of August. 
This is followed by Microcystis flos aquae (3.2\%), Oscillatoria $(0.03 \%)$ and Asterionella Formosa $(1.2 \%)$ was abundant in July with $23 \%$ population.

The mid-July phytoplankton sampling showed an abundance of Asterionella Formosa (23\%) followed by Ceratium hirudinella $(11 \%)$. Early August phytoplankton shows an abundance of Oscillatoria (19\%) followed by Microcystis flos aquae (14\%).
There was great diversity in the samples with the major group Chlorophytes (15 species), Cyanobacteria 13 species, Baccillariophytes (10 species), Cryptophytes (4 species), Euglenophytes (3 species) Chrysophytes and Dinophytes (2 species each). The t-test showed a significant difference in phytoplankton species composition between June and August $2004(\mathrm{t}=1.31 ; \mathrm{N}=49 ; \mathrm{P}=0.05)$.

Table1: Phytoplankton Class and the percentage of abundance in the lake

\begin{tabular}{|l|l|l|l|}
\hline Class & Species diversity & Total Number (cells/ml) & Percentage abundance (\%) \\
\hline Baccilariophytes & 10 & 260.047 & 7.127 \\
\hline Chlorophytes & 15 & 158.613 & 4.347 \\
\hline Cryptophytes & 4 & 48.91 & 1.341 \\
\hline Cyanophytes & 13 & 451.667 & 12.380 \\
\hline Dinophytes & 2 & 2638.81 & 72.330 \\
\hline Crysophytes & 2 & 35.67 & 0.978 \\
\hline Euglenophytes & 3 & 54.57 & 1.496 \\
\hline
\end{tabular}

Table 2: Physical and chemical parameters

\begin{tabular}{|l|l|l|l|}
\hline & A & B & C \\
\hline Chlorophyll-a $(\mu \mathrm{g} / \mathrm{l})$ & 34.89 & 24.33 & 20.94 \\
\hline Nitrates/Nitrites(mg/l) & 0.273 & 0.233 & 0.224 \\
\hline Ammonia(mg/l) & 0.036 & 0.048 & 0.041 \\
\hline Soluble reactive Phosphate $(\mathrm{mg} / \mathrm{l})$ & 5.79 & 11.29 & 10.07 \\
\hline Silicon $(\mathrm{mg} / \mathrm{l})$ & 0.219 & 0.176 & 0.054 \\
\hline Conductivity $(\mathrm{ms} / \mathrm{cm})$ & 0.203 & 0.198 & 0.198 \\
\hline pH & 7.97 & 7.81 & 7.39 \\
\hline Depth $(\mathrm{m})$ & 1.23 & 1.45 & 1.26 \\
\hline Dissolved Oxygen $(\%)$ & Mean level 87.06 & 12.092 & \\
\hline Temperature $\left({ }^{\circ} \mathrm{C}\right)$ & Mean level 16.95 & 0.1861 & \\
\hline
\end{tabular}

In terms of diversity, Chlorophytes were the most diverse species (15) followed by Cyanophytes. However, in terms of abundance, Dinophytes had the largest quantity among the groups with $72 \%$ even though it had 2 diverse species. (Table 1)The least abundant of the group were the Chrysophytes with about $1 \%$.

The water quality was detected and measured by using biological, chemical and physical analysis.

Phytoplankton: Phytoplankton analysis, which includes species count and biomass determination, could be used as an indicator to water quality (Reynolds et al., 2000). The results of this analysis indicated Ceratium hirudinella (Dinophytes) to be the most abundance species among the lake's phytoplankton composition. The dominance of Ceratium spp. may be related to the fluctuating weather conditions of the lake at the end of August when the temperature increased to $17^{\circ} \mathrm{C}$. Following this ranking were Microcystis flos aquae and Oscillatoria (Cyanophytes). The presence of Oscillatoria, a bloom forming alga and its group's non-dominance in this analysis gives an indication that its presence does not necessarily imply the formation of blooms (Reynolds, 1984a). However, in using the analytical tool of freshwater phytoplankton, the dominance of Ceratium and the presence of some blue-green algae indicate the lake to be moderately rich in nutrients. (Mesotrophic-eutrophic).

The presence of other minor species of Eudorina, Scenedesmus and Elakatothrix; Synedra and Cyclotella (Diatom); Dinobryon, Sphaerocystis, Staurastrum spp, Cosmarium sp and Tabellaria all indicated the lake to be moderately rich in nutrients (mesotrophic) and the presence of Cyanophytes like Oscillatoria agardhii, Microcystis, Aphanizomenon, 
Chlorella and Anabaena were indicators of a nutrientrich lake.

Chlorophyll-a: There was abundant quantity of biomass in site A because it was the lake's overflow and had a nature reserve which eroded into the lake. A comparison of the chlorophyll-a result with the Technical Standard TGL 27885/01(Technical Standard., 1982) showed that the lake can be categorised into the mesotrophic-eutrophic status and thus moderately polluted.

Physical analysis and Water quality: Temperature: The temperature of the lake was higher at the surface and gradually decreased when the thermometer was lowered to the depth of $8 \mathrm{~m}$. The highest temperature recorded was $19.95^{\circ} \mathrm{C}$ at the $2^{\text {nd }}$ week in August. By the last week of August, the temperature had dropped to $17^{\circ} \mathrm{C}$. Sudden fluctuations do not really have immediate effects on the temperature of lakes due to lack of water movement and the establishment of a thermocline. (Hutchinson, 1967). However, the water temperatures of turbulent streams that are relatively narrow and shallow are influenced by rapid changes in air temperature. (Reid 1961). In this study, the results indicated that the lake was influenced by air temperature and the water temperature fluctuations might have been attributed to the presence of minimal thermal stratification.

Dissolved Oxygen: This is one of the most important factors used in determining the quality of water (Odum 1956).The lower the depth of the lake, the lower the dissolved oxygen content measured. The results indicated that the dissolved oxygen content was significantly affected by water depth due to minimal thermal stratification.

Phosphate: In many aquatic systems, the limiting nutrient is usually phosphate and this is especially true of lakes and stagnant bodies of water. (Hutchinson 1967). In streams whose course takes them through terrains made up of agricultural and residential areas, phosphates can be expected to be found in higher concentrations than those that drain non-agricultural areas (Reid, 1961). As surface water runoff enters a stream it carries silt load and inorganic phosphates which are washed from the soil. This could have been the case in this study as phosphate level was at its highest at site B $(11.29 \mathrm{mg} / \mathrm{l})$ as the site was closer to the harbour and the bridge. Site $C$ had phosphate level of $10.07 \mathrm{mg} / 1$ and could be attributed to its closeness to the visitor centre which had car parks and a car wash, liquid detergent from this process flowed directly into the lake. Minimal dilution could also have resulted in the high level of phosphate found in these two sites.
Nitrates/Nitrites: The levels of Nitrates/Nitrites for the sites were found to be low with $0.24 \mathrm{mg} / \mathrm{l}$. When compared with standards for WHO and EC's Water Framework Directive, the results indicated that there was no surface water runoff from domestic sewage nor agricultural sources.

Ammonia: The WHO's standard for ammonia in drinking water is $0.5 \mathrm{mg} / \mathrm{l}$. The mean levels of ammonia for the 3 sites A, B and C were 0.042 . The result indicated that there was little or no influx of sewage into the lake (WHO, 1993)

Conductivity: The Lake had a conductivity level of $0.199 \mathrm{mS} / \mathrm{cm}$ which is low in comparison to the standards for World Health Organisation and the EU requirements of $250 \mathrm{microS} / \mathrm{cm}$. This result implied that the concentration of free metal ions is in short supply in the lake. As such, the formation of metal complexes and consequently, metal pollution could not be enhanced.

Transparency: Transparency analysis using the Technical Standard TGL 27885/01(Technical Standard., 1982) and the keys of Makie et al (2000) indicated the lake to be mesotrophic.

Conclusion: The assemblages of phytoplankton in Hollingworth Lake were indicative of the lake's richness based on species' abundance and diversity. The analysis of nutrients present in the lake was an indicator of how healthy the lake was and the number of species found there was dependent on the concentration of the nutrients in the lake. These complementary analyses provide a better understanding of the lake's present condition (Arfi et al, 2003) and their information can be used to mitigate negative effects. Limited quantities of ammonia and the nitrates point to the fact that there was little influx of silt and organic nutrients from the lake's agricultural lands and residential surroundings. The low conductivity level was also indicative of the lake's minimal pollution. Consequently, the physical, biological and chemical analyses were further accentuated in this paper as holistic indicators that are capable of assessing lake water quality. Consequently, the results of this paper when compared with the EC's Water Framework Directive 2000/60/EC for lakes could be said to be of moderately good water quality status and does not pose any problem to the socio-economic status of the lake and its surroundings.

\section{REFERENCES}

Arfi R, Bouvy M, Cecchi P, Corbin D, Pagano M (2003) Environmental conditions and phytoplankton assemblages in two shallow reservoirs of Ivory Coast (West Africa). Archiv Fur Hydrobiologie 156: 511534 
Brettum P and Andersen T. (2005) The use of phytoplankton as indicators of water quality.NIVAreport SNO 4818-2004

EC's Water Framework Directive http://ec.europa.eu/environment/water/waterframework/index_en.html

Odum, H. T. (1956). Primary Production in flowing waters. Limnol.and Oceanog. 1: 102-117.

Reynolds C.S. and Peterson A. C (2000).The distribution of planktonic Cyanobacteria in Irish Lakes in relation to their trophic states. Hydrobiologia 424, 91-99

Reynolds, C., Huszar V., Kruk C., Naselli-Flores L. \& Melo S(2002) Towards a functional classification of the freshwater phytoplankton. J. Plankton Res. $24: 417-428$

Downing, J. A. and Rigler, F.H. (1984). A manual on Methods for the Assessment of Secondary Productivity in fresh Waters (2nd ed.) Blackwell Scientific Publications, Oxford.

Hutchinson, G. E. (1967). A treatise on limnology. Vol. II. Introduction to lake biology and the limnoplankton. John Wiley \& Sons, Inc., N. Y. pp 1115

Cander-Lund, H., Lund, J.W.G. (1995) Freshwater Algae. Their Microscopic World Explored, Biopress Ltd., England, UK; pp 360

Lund, J.W. Kipling, G.C., and Le Cren, E. E., (1958). The inverted microscope method of estimating algal numbers and the statistical basis of estimation by counting
Mackie, G.L., Hincks, S., and Barker, D. (2000). Introduction to Aquatic Environments, Course Manual, University of Guelph. 11 chapters, 5 appendices

Moss B. (1998). Ecology of Freshwaters Man and A medium, past to Future, $3^{\text {rd }}$ edition, Blackwell Science Ltd.

Reid, G. K. (1961). Ecology of inland waters and estuaries. Reinhold Publ. Corp., N. Y.375

Reynolds C.S. (1984a) the Ecology of freshwater phytoplankton, Cambridge University Press, Great Britain.

Reynolds C.S. (1997) Vegetation Processes in the pelagic. A model for ecosystem theory. In: Kinne O. (ed.), Excellence in ecology, Ecology Institute, Oldendorf/Luhe, Germany, pp 1-371

Skalar Analytical,B.V. (1993) Skalar Automated N \&P analyser. Publication No: 0711293. Headquarters Skalar Analytical B.V., P.O.Box 3237, 4800, DeBREDA, The Netherlands

Straskraba, M. and Tundisi, J.G. (1999). Reservoir Water Quality Management. Guidelines of Lake Management. Volume 9. International Lake Environment Committee (ILEC) Shiga, Japan.

Technical Standard. (1982) Nutzung and Schutz der Gewasser. Stehende Binnengewasser. Klassifizierung.(In German:Utilisation and protection of water bodies. Standing inland water classification).technical standard 27885/01, Berlin, German Democratic Republic, April 30, 1982, pp.16.

WHO (1993) Drinking water standards. http://www.lenntech.com/applications/drinking/stand ards/who-s-drinking-water-standards.htm. 